\title{
Periphyton nutrient content, biomass and algal community on artificial substrate: response to experimental nutrient enrichment and the effect of its interruption in a tropical reservoir
}

\author{
Suele Aparecida Mendes Santos ${ }^{1} \cdot$ Thiago Rodrigues dos Santos $^{1} \cdot$ Mariana S. R. Furtado ${ }^{2} \cdot$ Raoul Henry $^{2}$. \\ Carla Ferragut ${ }^{1}$ (D)
}

Received: 13 March 2017 / Accepted: 5 November 2017 / Published online: 24 November 2017

(C) The Japanese Society of Limnology 2017

\begin{abstract}
Periphyton plays an important functional role in the retention of nutrients in aquatic ecosystems, especially phosphorus. We evaluated the effects of enrichment with $\mathrm{N}$ and $\mathrm{P}$ and the effect after 20 days of no additional $\mathrm{N}$ and $\mathrm{P}$ on periphyton on artificial substratum in open-bottom mesocosms. The aim was to jointly evaluate periphyton, phytoplankton and zooplankton in the presence of macrophytes. Experimental conditions simulated natural conditions and nutrient addition was based on the maximum concentration recorded in mesotrophic reservoir. Our hypothesis is that the periphyton is sensitive to the effects of $\mathrm{N}$ and $\mathrm{P}$ enrichment and its interruption, despite the positive response of phytoplankton and zooplankton. Two treatments were designed using open-bottom mesocosms $(n=3)$ : control (no nutrient addition); NP+ (combined phosphorus and nitrogen addition). Sampling for the measurement of biotic and abiotic variables was performed, with 10 days of continuous enrichment, on the 3rd, 6th and 11th, and 20 days after enrichment had ended (31st day). Periphyton chlorophyll $a$, dry mass and algal density increased significantly with the addition of $\mathrm{N}$ and $\mathrm{P}$ and decreased 20 days after the interruption of the enrichment. The highest periphyton P content was found in the NP+ treatment. The enrichment had a positive effect on Chrysophyceae (Chromulina spp.) and rotifer (Polyarthra spp.) density and the interruption of enrichment favored Bacillariophyceae (Gomphonema sp.) and rotifers (Gastropus stylifer). Phytoplankton responded positively to enrichment. Along with the high macrophyte coverage over the experimental period, we evidenced the positive effect enrichment had on phytoplankton biomass and zooplankton abundance. Therefore, periphyton on artificial substrate was sensitive to effects of $\mathrm{N}$ and $\mathrm{P}$ enrichment and its interruption, responding promptly to changes in nutrient availability in a scenario of high competition and grazing.
\end{abstract}

Keywords Macrophyte coverage $\cdot$ Phytoplankton chlorophyll $a \cdot$ Periphyton $\mathrm{N}$ and $\mathrm{P}$ content $\cdot$ Zooplankton

\section{Introduction}

Periphyton plays a significant role in the nutrient cycling, energy flow and food web of aquatic ecosystems (Vadeboncoeur and Steinman 2002). Changes in the biomass and

Handling Editor: Richard Sheibley.

Carla Ferragut

cferragut@ibot.sp.gov.br

1 Instituto de Botânica, Núcleo de Pesquisas em Ecologia, São Paulo, SP Caixa Postal 68041, Brazil

2 Departamento de Zoologia, Instituto de Biociências, Campus de Botucatu', Universidade Estadual Paulista, UNESP, Rubião Júnior, Botucatu, SP CEP 18618-970, Brazil taxonomic structure of the periphytic algae community can provide information on changes in environmental conditions, and can serve as a tool for ecological assessment (McCormick and Stevenson 1998; Stevenson and Smol 2003). Studies have evidenced that periphyton-based metrics can be reliable indicators of the onset of the eutrophication process (Gaiser et al. 2004, 2006). The success of periphytic algae in colonizing substrates and persisting in the community depends primarily on resource availability and the efficiency of their adaptive strategies to compete for resources (Stevenson 1996). Despite the ecological importance of periphyton, changes in community structure due to environmental changes are still not well understood, particularly in shallow tropical reservoirs and lakes. 
The development of the periphytic algae community depends on a complex series of interactions between abiotic and biotic factors; this includes nutrient and light availability and the substrate type, which act as determining factors (Stevenson 1997). There is consensus in the literature that variations in nutrient availability can promote the redirection of a successional trajectory and change the biomass accrual rate in the periphyton (Sekar et al. 2002). Previous studies have reported the strong effect of enrichment on the colonization and succession of the periphytic algae community in tropical reservoirs (e.g., Ferragut and Bicudo 2012). Experimental studies have evaluated the effect of enrichment on autotrophs and grazers (Jones et al. 2002; Olsen et al. 2015; Zhang et al. 2016), but the interactive effects on periphyton response are poorly explored. Biotic factors may also be determinants for the periphyton community structure, especially competition and grazing (Stevenson 1997). Complex interactions can determine how an ecosystem responds to artificial enrichment (nutrient stress), mainly because enrichment can change the equilibrium between primary producers (Havens et al. 2001). Thus, the response of periphyton to experimental enrichment may be more representative of natural conditions in the presence of its main competitors for resources.

Periphyton responds promptly to physical and chemical disturbances, but the competitive interactions and autogenic changes can greatly influence community development (Sand-Jensen and Borum 1991; Hillebrand and Kahlert 2001). Chemical disturbances, such as enrichment, can also influence the resilience (the ability to return to the pre-disturbance state) of the community to environmental changes (Peterson and Stevenson 1992). Regarding the natural nutrient conditions, the current reservoir is mesotrophic, and phosphorus is considered the primary limiting nutrient of periphytic algal growth (Ferragut et al. 2010). Furthermore, the higher macrophyte aquatic cover plays a significant role in ecosystem functioning, especially due to macrophyte influence on development of the algal communities (Fonseca and Bicudo 2011; Souza et al. 2015). We evaluated the effects of enrichment by $\mathrm{N}$ and $\mathrm{P}$, as well as the effect of stopping this chemical disturbance, on periphyton and its relationships with phytoplankton and zooplankton in the presence of macrophytes. Periphyton was evaluated within an experimental scenario a little closer to natural conditions. The response of the periphyton to nutrient enrichment can be affected by some characteristics of the other communities, such as the rapid assimilation of nutrients by phytoplankton (Hwang et al. 1998); the control of P release by photosynthetically active epipelon (Genkai-Kato et al. 2012); shading by macrophytes, which reduces photosynthetic activity (McCormick and Stevenson 1998) and grazing on periphytic algae (Jones et al. 2000). The periphyton response to enrichment was analyzed through changes in nutrient content, biomass and algae community structure. Our hypothesis is that periphyton responds differently during and after the shortterm addition of $\mathrm{N}$ and $\mathrm{P}$, despite the positive response of phytoplankton and zooplankton. Specifically, we intend to answer two questions: (1) Does $\mathrm{N}$ and $\mathrm{P}$ enrichment have a positive effect on biomass and change the periphyton structure? (2) Can enrichment by $\mathrm{N}$ and $\mathrm{P}$ and its stoppage change the taxonomic structure and biomass accrual in periphyton? The present study aims to contribute to a better understanding of periphyton responses to variations in the nutrient concentration in tropical shallow lakes and reservoirs.

\section{Materials and methods}

\section{Study area}

Periphyton was studied in Ninfeias Reservoir $\left(23^{\circ} 38^{\prime} 18.95^{\prime \prime} \mathrm{S}\right.$ and $\left.46^{\circ} 37^{\prime} 16.3^{\prime \prime} \mathrm{W}\right)$, located in the Parque Estadual das Fontes do Ipiranga (PEFI), São Paulo, Brazil. This reservoir is small, shallow and mesotrophic. The reservoir has surface area of $5433 \mathrm{~m}^{2}$, mean depth of $1.32 \mathrm{~m}$, maximum depth of $3.6 \mathrm{~m}$, and mean theoretical residence time of 7.2 days (Bicudo et al. 2002). The reservoir has an extensive littoral zone with abundance of aquatic macrophytes, such as Nymphaea spp. (rooted and leaves floating), Utricularia foliosa L. (free floating) and Panicum repens L. (rooted grass).

\section{Experimental design}

The effect of the variation in nutrient availability on the periphyton was evaluated for 10 days of continuous enrichment and 20 days after enrichment had ended (16 September-17 October 2014). The enrichment experiment was performed in situ in open-bottom mesocosms, which were made of transparent acrylic cubes $(1 \mathrm{~m} \times 0.6 \mathrm{~m} \times 0.6 \mathrm{~m}, 316.81$ volume). The experiment consisted of two replicated treatments $(n=3)$ : $\mathrm{C}$, control (no $\mathrm{N}$ and $\mathrm{P}$ addition); $\mathrm{NP}+$, combined $\mathrm{P}$ and $\mathrm{N}$ addition. Three mesocosms of each treatment (triplicate) were placed in the shallowest part of the reservoir (depth $0.8 \mathrm{~m}$ ). The mesocosms were firmly pressed and buried $10 \mathrm{~cm}$ deep in the sediment. Each mesocosm was secured to a metal rod that prevented displacement. After the installation of the mesocosms, there was an interval for acclimatization (09/12-10/15/2014).

We determined daily DIN (dissolved inorganic nitrogen) and $\mathrm{P}-\mathrm{PO}_{4}$ concentration in the mesocosms. Based on the daily determination of the $\mathrm{DIN}$ and $\mathrm{P}-\mathrm{PO}_{4}$ concentrations in the mesocosms, we added enough nitrogen $\left(\mathrm{NaNO}_{3}\right.$ Merck) and phosphorus $\left(\mathrm{KH}_{2} \mathrm{PO}_{4}\right.$ Merck) to maintain the $\mathrm{N}: \mathrm{P}$ molar ratio at 16 in the NP+ treatment. The enrichment aimed to increase the phosphorus availability to $38 \mu \mathrm{g} \mathrm{P}-\mathrm{PO}_{4} 1^{-1}$ and keep the N:P molar ratio equal or close to 16 (a lower ratio recorded in the reservoir). The value of the selected $\mathrm{P}-\mathrm{PO}_{4}$ 
concentration refers to the highest TP concentration found in the pelagic region, because ambient concentrations were always below the detection limit of the method $\left(<4 \mu \mathrm{g} \mathrm{l}^{-1}\right)$.

Periphyton on artificial substrate was sampled on the $3 \mathrm{rd}$, 6th, 11th and 31st days of colonization. On these days, water sampling for the physical, chemical and biological variables was performed. Six transparent acrylic slides $\left(199.92 \mathrm{~cm}^{2}\right)$ were inserted and fixed in a vertical position at a depth of $25 \mathrm{~cm}$ inside each mesocosm for periphyton colonization. One substrate colonized by periphyton was randomly removed from the mesocosms on the sampling day. The periphyton was removed from the substrate by scraping with a soft bristle brush and distilled water jets in the laboratory. Periphyton subsamples were separated for the determination of community attributes.

\section{Abiotic and biotic variables analyzed}

Surface water samples were collected from the mesocosms using polyethylene bottles for determining abiotic variables and characterizing phytoplankton communities. The following abiotic variables were determined on the sampling day: temperature, electric conductivity, $\mathrm{pH}$ (Horiba U-51), nitrite $\left(\mathrm{N}-\mathrm{NO}_{2}\right)$ and nitrate $\left(\mathrm{N}-\mathrm{NO}_{3}\right)$ (Mackereth et al. 1978), ammonium $\left(\mathrm{N}-\mathrm{NH}_{4}\right)$ (Solorzano 1969), orthophosphate $\left(\mathrm{P}-\mathrm{PO}_{4}\right)$ and total dissolved phosphorus (TDP) (Strickland and Parsons 1960), total nitrogen (TN), total phosphorus (TP).

In the mesocosms, 51 of water was collected for the determination of zooplankton density using a tube sampler (PVC tube with a $10-\mathrm{cm}$ diameter); the water was then filtered through a 50- $\mu \mathrm{m}$ mesh net. In order to avoid the contraction of organisms, the process of narcotization with $\mathrm{CO}_{2}$ saturation was accomplished through the addition of carbonated water.

The macrophyte present in the mesocosms was Nymphaea spp., which is quite abundant in the reservoir. The Nymphaea leaves were cut to standardize the number of leaves in the mesocosms during the experimental period (on average 14 leaves). Macrophyte coverage was determined by multiplying the number of leaves by the mean leaf area $\left(\mathrm{cm}^{2}\right)$ in each mesocosm. The leaf area was calculated using the Image J program 1.47 (Rasband 2008).

We determined phytoplankton and periphyton chlorophyll $a$ (corrected for phaeophytin) concentration from subsamples filtered with glass-fiber filters (GF/F Whatman, Maidstone, UK), following $24 \mathrm{~h}$ extraction with $90 \%$ ethanol in the dark (Sartory and Grobbelaar 1984). Periphyton dry mass (DM) was determined by filtration of subsamples into pre-calcined glass-fiber filters (GF/F Whatman), which were stored $\left(100{ }^{\circ} \mathrm{C}\right)$ and weighed daily until constant mass was obtained (APHA 2005).
Periphyton subsamples were preserved with a $4 \%$ formalin solution for qualitative analysis and with an acetic Lugol solution for quantitative analysis. Algal quantifications were performed under a Zeiss Axiovert microscope (400x) according to Utermöhl (1958), and subsample sedimentation time was measured in sedimentation chambers following Lund et al. (1958). The counting limit was determined using the species rarefying curve. We considered descriptor species those with relative density $\geq 10 \%$ and dominant species those with a relative density $\geq 50 \%$.

Periphyton phosphorus content was determined by combustion of the subsamples at $550{ }^{\circ} \mathrm{C}$ for $1 \mathrm{~h}$, and then the samples were heated with $1 \mathrm{~N} \mathrm{HCl}$ at $80{ }^{\circ} \mathrm{C}$ for $30 \mathrm{~min}$ (Andersen 1976; Pompêo and Moschini-Carlos 2003). Subsequently, the $\mathrm{P}-\mathrm{PO}_{4}$ concentration was determined using the ascorbic acid method (Strickland and Parsons 1960). Periphyton nitrogen content was determined using the micro-Kjeldahl method. Nitrogen (TN) and phosphorus (TP) content was expressed as percentage of dry mass (\% DM).

The quantitative analysis of the zooplankton was performed on an acrylic plate, checked under a microscope with 50× magnification, for Cladocera and Copepoda. The counts of Rotifera and Copepoda nauplii were carried out in a Sedgewick-Rafter chamber under an optical microscope with a magnification of $100 \times$. The limit count was determined using the species rarefaction curve.

\section{Data analysis}

We used two-way ANOVA to determine statistical differences in the DIN, $\mathrm{P}-\mathrm{PO}_{4}$ and $\mathrm{N}: \mathrm{P}$ ratio between treatments and time, and two-way repeated-measures ANOVA (RM ANOVA) to determine the effects of enrichment and time on periphyton attributes ( $\mathrm{N}$ and $\mathrm{P}$ content, chlorophyll $a$, dry mass and algal density) and zooplankton density. The Tukey and Student Newman-Keuls (SNK) tests, a posteriori comparison of means, were used to detect the minimum significant difference between treatments $(\alpha=0.05)$, and were performed using the statistical program SigmaPlot 11.0.

Cluster analysis was performed to determine the similarity in species composition of the periphytic algae community between treatments. This analysis was performed with an algal density matrix, using mean association (UPGMA) and the Simpson index application. Non-parametric permutational multivariate analysis of variance (two-way PERMANOVA) was applied to analyze the effect of enrichment on the taxonomic structure of the periphytic algae community. This analysis was performed using Bray-Curtis similarity and 4999 permutations, and performed using Past 3.14 (Hammer et al. 2001). 


\section{Results}

\section{Abiotic variables}

During the enrichment period (4-15 days), $\mathrm{P}-\mathrm{PO}_{4}$ concentration in the $\mathrm{NP}+$ treatment was higher and significantly different from the control on the 3rd and 11th days (SNK: $p<0.001$ ). DIN concentration was higher and significantly different in the NP+ treatments from the control on the 3rd and 6th days (SNK: $p<0.03$ ). Twenty days after nutrient interruption, DIN concentration in the control was higher and significantly different from NP+ treatment (SNK: $p=0.006)$. The $\mathrm{N}: \mathrm{P}$ molar ratio in the control ranged from 11.9 to 21.1 and in the NP+ treatment, it ranged from 16.2 to 77.7 during the enrichment period. After the enrichment period the N:P molar ratio in the control was 61.9 and was 11.2 in the NP+ treatment (Table 1).

\section{Periphyton}

Periphyton chlorophyll $a$ and dry mass were significantly influenced by enrichment, colonization time, and the interaction of these two factors (Fig. 1a, b; ANOVA: $p<0.05$ ). Periphyton chlorophyll $a$ was significantly different between the control and NP+ treatment on the 3rd, 6th and 11th days (Tukey test: $p<0.05$ ). In the NP+ treatment, the maximum value of periphyton chlorophyll $a$ was reduced by 3.4 times, 20 days after enrichment had ended. Periphyton dry mass increased exponentially in NP+ treatment and fluctuated in the control, but the significant difference occurred only on the 3rd day of colonization (Tukey test: $p<0.05$ ).

Periphyton $\mathrm{P}$ content showed a significant difference between NP+ treatment and the control on the 3rd, 6th and 11th days (Fig. 1c; Tukey test: $p<0.05$ ). We found

Table 1 Average and standard deviation of DIN, $\mathrm{P}-\mathrm{PO}_{4}$ and NP molar ratio in the control and treatment with $\mathrm{N}$ and $\mathrm{P}$ combined addition $(\mathrm{NP}+)$ on sampling day

\begin{tabular}{lllll}
\hline Days & Treatments & Variables & & \\
\cline { 3 - 5 } & & DIN $\left(\mu \mathrm{g} \mathrm{l}^{-1}\right)$ & $\begin{array}{l}\mathrm{P}-\mathrm{PO}_{4} \\
\left(\mu \mathrm{g} \mathrm{l}^{-1}\right)\end{array}$ & NP ratio \\
\hline 3rd day & Control & $9.0 \pm 2.1$ & $<4.0$ & $11.9 \pm 2.7$ \\
& $\mathrm{NP}+$ & $102.5 \pm 83.7^{*}$ & $7.7 \pm 3.2^{*}$ & $33.9 \pm 35.7$ \\
6th day & $\mathrm{Control}$ & $14.7 \pm 2.4$ & $<4.0$ & $19.4 \pm 3.2$ \\
& $\mathrm{NP}+$ & $129.2 \pm 25.8^{*}$ & $<4.0$ & $77.7 \pm 17.5^{*}$ \\
11th day & $\mathrm{Control}$ & $28.4 \pm 9.1$ & $<4.0$ & $21.1 \pm 11.2$ \\
& $\mathrm{NP}+$ & $97.0 \pm 16.3$ & $13.3 \pm 1.4^{*}$ & $16.2 \pm 3.6$ \\
31st day & $\mathrm{Control}$ & $136.6 \pm 96.8$ & $4.3 \pm 2.3$ & $61.9 \pm 24.8$ \\
& $\mathrm{NP}+$ & $15.4 \pm 13.0^{*}$ & $<4.0$ & $11.2 \pm 2.2^{*}$ \\
\hline
\end{tabular}

*Significant difference between control and NP+ treatment the lowest periphyton $\mathrm{P}$ content in the NP+ treatment on the 31 st day of colonization. Periphyton $\mathrm{N}$ content showed statistically significant interaction between enrichment and time factors (Fig. 1d). Periphyton $\mathrm{N}$ and $\mathrm{P}$ content had significant difference among treatments on the $3 \mathrm{rd}$ and 11 th days (Tukey test: $p<0.05$ ).

Regarding periphytic algae community structure, we found that algal density was significantly influenced by enrichment, colonization time, and the interaction of these two factors (Fig. 2; ANOVA: $p<0.05$ ). Multiple comparisons for enrichment factor showed that periphyton algal density was significantly different between the control and $\mathrm{NP}+$ treatment on the $3 \mathrm{rd}$, 6th and 11th days (Tukey test: $p<0.05)$.

A total of 59 periphytic algae species were identified in the treatments. These species belong to the following algal classes: Bacillariophyceae, Chlorophyceae, Chrysophyceae, Cryptophyceae, Cyanobacteria, Euglenophyceae and Zygnemaphyceae. Chrysophyceae and Bacillariophyceae were the most representative algal classes in the community structure (Fig. 3). In the control, Chrysophyceae (32\%), Cyanobacteria (22\%) and Euglenophyceae (19\%) had high relative densities on the 6th day of colonization, but later Chrysophyceae dominated (> 50\%). Chrysophyceae $(60 \%)$ was the class most representative in the control and $\mathrm{NP}+$ treatment during the enrichment period. Bacillariophyceae (50\%) was dominant in NP+ treatment and Chrysophyceae maintained dominance in the control 20 days after enrichment had ended ( 31 st day).

Periphyton species composition changed over time in the control and NP+ treatment (Fig. 4). In the control, Chromulina spp. and Chroococcus sp. were the most abundant taxa in the periphyton on the 3rd and 6th days of colonization, while Chromulina spp. and Synechocystis aquatilis were more abundant on the 11th and 31st days. In the $\mathrm{NP}+$ treatment, Chromulina spp. was the most representative species on the 3rd, 6th and 11th days of colonization. Despite the dominance of Chromulina spp., the relative density was higher in the NP+ treatment compared to the control (Fig. 4b). The highest Chromulina spp. density occurred on the 6th day in the NP+ treatment, representing $60 \%$ of the total density. Diatom Gomphonema sp. had the highest relative density in the NP+ treatment 20 days after enrichment ended (31st day).

Two-way PERMANOVA showed that the periphytic algae community structure was significantly influenced by enrichment and time factors $(p<0.01)$, but there was no significant interaction between the two factors.

Clustering analysis showed the formation of two groups at a similarity level of 54\%: control and treatment (Fig. 5). The highest similarity in species composition was found between the 6th and 11th days (70\%) in the control group. 

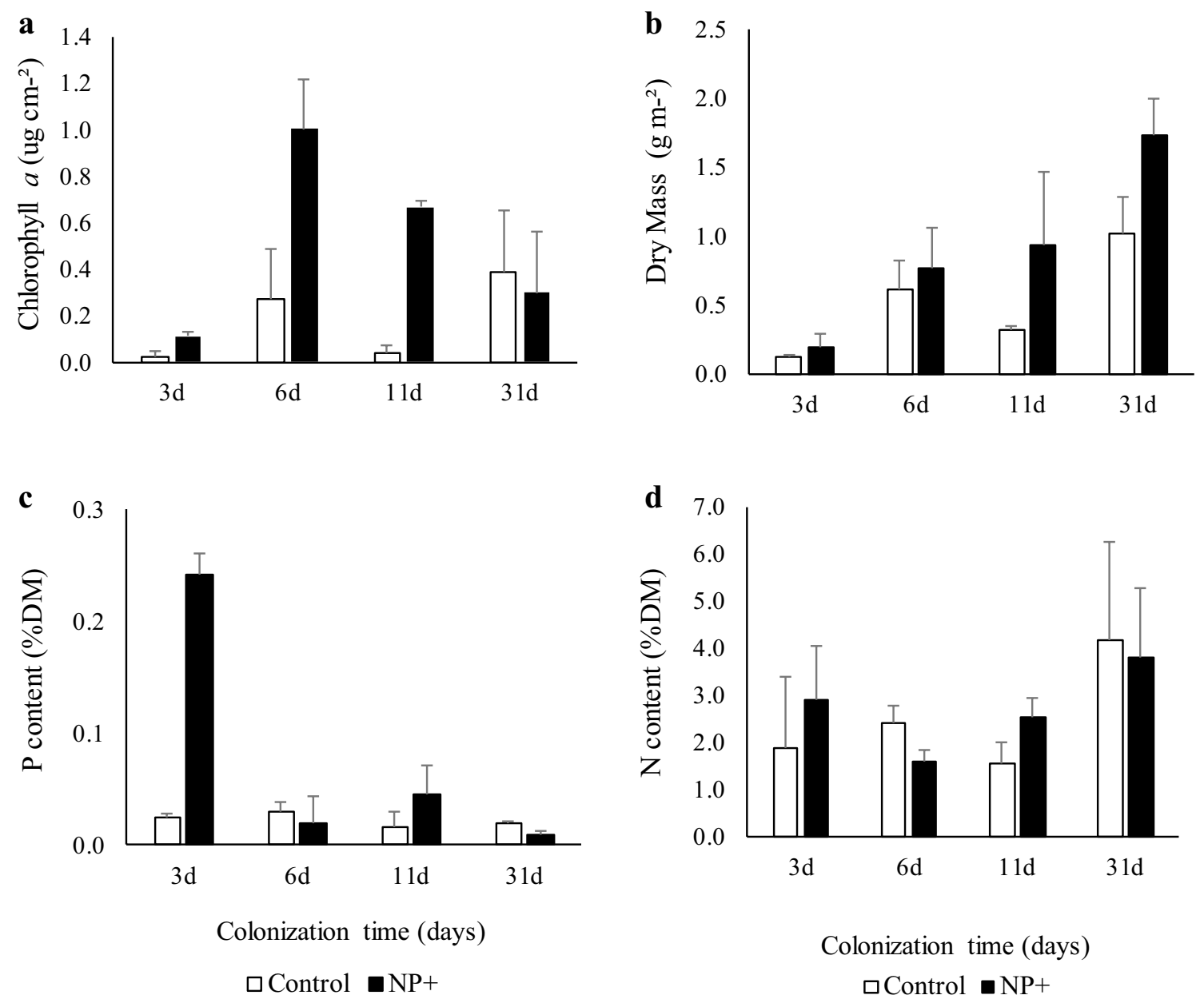

Fig. 1 Periphyton chlorophyll $a$ (a), dry mass (b), phosphorus (c) and nitrogen (d) content $(n=3$; \pm SD) in control and combined $\mathrm{N}$ and $\mathrm{P}$ addition treatment $(\mathrm{NP}+)$ during the enrichment continuous period (3rd, 6th, 11th days) and 20 days after its interruption (31st day)

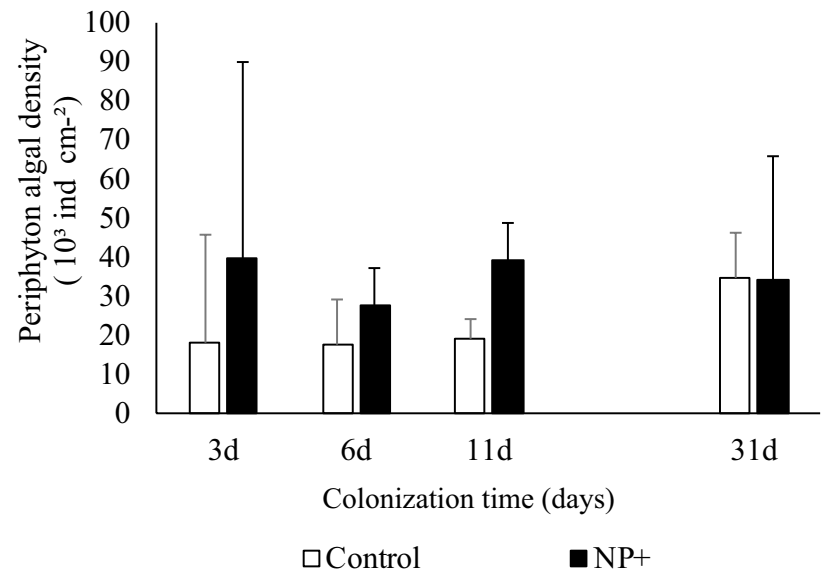

Fig. 2 Periphyton total density in control (C) and combined $\mathrm{N}$ and $\mathrm{P}$ addition treatment $(\mathrm{NP}+)$ during the enrichment continuous period (3rd, 6th, 11th days) and 20 days after its interruption (31st day)
The same result was also observed in the NP+ treatment (75\% similarity).

\section{Macrophyte and phytoplankton}

The Nymphaea spp. coverage stayed constant in both the control and $\mathrm{NP}+$ treatment during the experimental period, ranging from 49.3 to $57.0 \%$ in the control and $57.0-66.1 \%$ in NP+ treatment during the enrichment period. After the enrichment period, the Nymphaea spp. average coverage was $70 \%$ in the control and $79 \%$ in the NP+ treatment.

Phytoplankton chlorophyll $a$ varied from 3.5 to $14.1 \mu \mathrm{g} \mathrm{l}^{-1}$ in the control and from 22.0 to $78.2 \mu \mathrm{g} \mathrm{l}^{-1}$ in the NP+ treatment (Fig. 6a). After the enrichment period, phytoplankton chlorophyll $a$ was $12.9 \mu \mathrm{g} \mathrm{l}^{-1}$ in the control and $9.1 \mu \mathrm{g} \mathrm{l^{-1 }}$ in the $\mathrm{NP}+$ treatment. 
Fig. 3 Relative density of periphytic algae class $(n=3)$ in combined $\mathrm{N}$ and $\mathrm{P}$ addition treatment $(\mathrm{NP}+)$ during the enrichment continuous period (3rd, 6th, 11th days) and 20 days after its interruption (31st day)

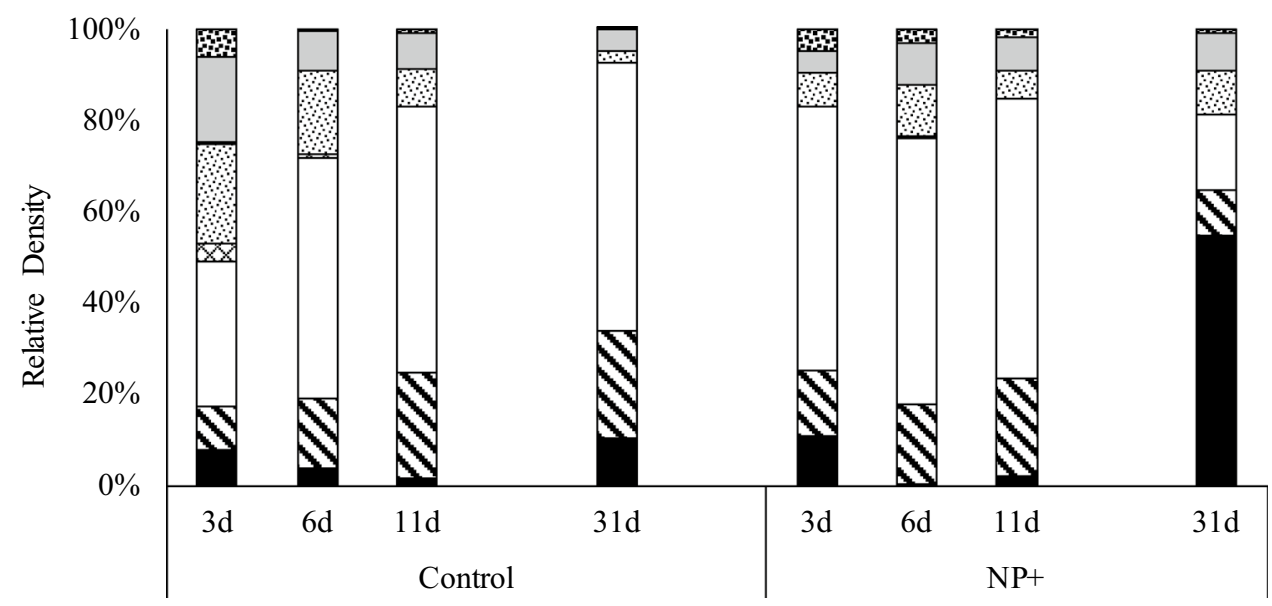

Bacillariophyceae \$Chlorophyceae $\square$ Chrysophyceae \&ryptophyceae DCyanobacteria minophyceae $\square$ Euglenophyceae Zygnemaphyceae

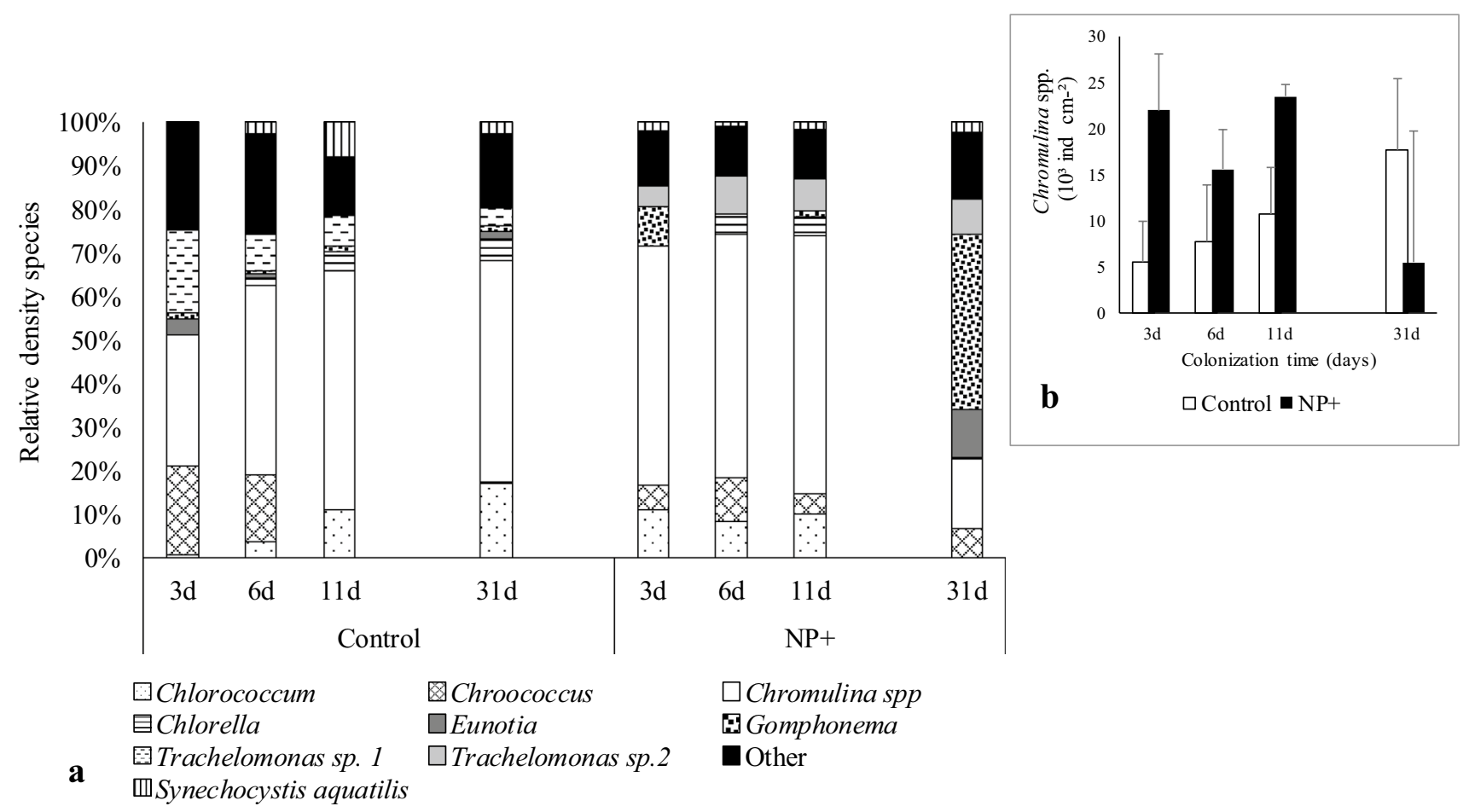

Fig. 4 Relative density of periphytic descriptor species (a) and Chromulina spp. density (b) in control and combined $\mathrm{N}$ and $\mathrm{P}$ addition treatment $(\mathrm{NP}+)$ during the enrichment continuous period (3rd, 6th, 11th days) and 20 days after its interruption (31st day)

\section{Zooplankton}

Zooplankton total density was significantly different between the control and the NP+ treatment during the enrichment period (Fig. 6b; RM ANOVA: $F=13.00 ; p=0.023$ ). Total density was significantly different only on the 11th day (Tukey test: $p<0.05$ ) and was 2.3 times higher than amounts found in the control on the 11th day. After 20 days without enrichment, zooplankton total density was not significantly different between treatments, but a significant difference could be observed between the 11th and 31st days in the NP+ treatment.

Considering taxa with a contribution greater than $10 \%$ to the community abundance, we verified that Polyarthra spp. (Rotifera) was the most favored species (Table 2). Twenty days after enrichment ended (31st day), we 


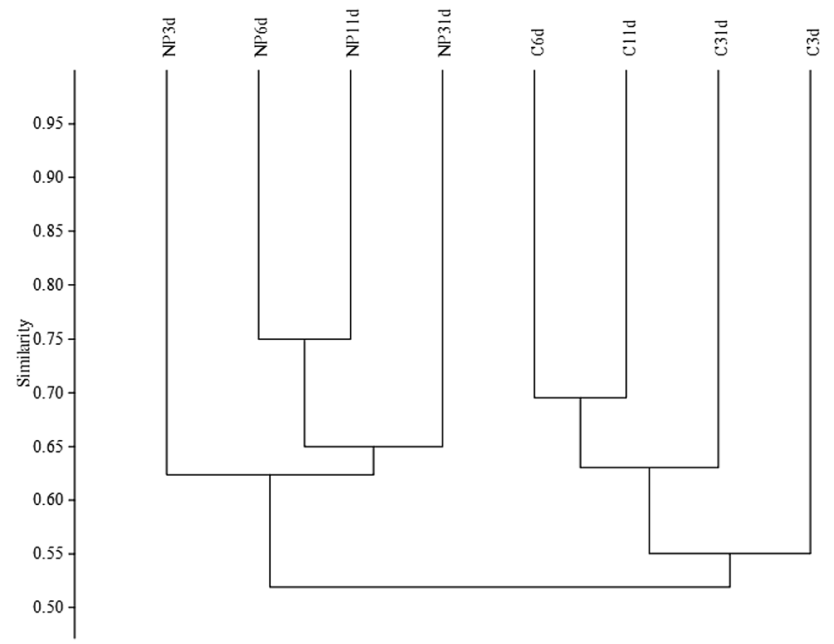

Fig. 5 Similarity of species composition of periphytic algae in control $(\mathrm{C})$ and combined $\mathrm{N}$ and $\mathrm{P}$ addition treatment $(\mathrm{NP}+$ ) during the enrichment continuous period (3rd, 6th, 11th days) and 20 days after its interruption (31st day)

observed a decrease in average density of Polyarthra spp. and an increase of Gastropus stylifer (Rotifera) in the NP+ treatment.

\section{Discussion}

Our experimental results showed that combined addition of $\mathrm{N}$ and $\mathrm{P}$ had a positive and significant effect on biomass, $\mathrm{P}$ content and algal density in the periphyton on artificial substrate. In addition, the taxonomic structure of the periphytic algae community changed with the combined addition of $\mathrm{N}$ and $\mathrm{P}$, but changes also occurred 20 days after enrichment had ended. On the 31 st day of colonization, there was a reduction in algal growth and biomass accumulation in periphyton. The enrichment period favored the increase of rotifer density in the water, mainly Polyarthra spp., which is a raptorial rotifers and commonly plant-associated (Obertegger and Flaim 2015; Romo et al. 2004). Although water temperature is a determining factor for population dynamics of the Polyarthra (Virro 1995), enrichment can act significantly on rotifer density (Romo et al. 2004). Based on the feeding habits of the most abundant species of zooplankton, we believe that the grazing pressure was low on the periphyton. We showed that the positive response of phytoplankton biomass and zooplankton density did not minimize the enrichment effect on the periphyton.

Our findings have shown that the positive response of periphyton chlorophyll $a$ and algal density to enrichment was not affected by the high phytoplankton abundance and macrophyte coverage throughout the experimental period. Besides nutrient competition, high phytoplankton abundance and macrophyte coverage could inhibit growth of periphyton due to strong shading (Genkai-Kato et al. 2012; Souza et al. 2015). Previous studies reported that high macrophyte coverage (80-100\%) and phytoplankton biomass can negatively influence periphyton biomass accrual (Casartelli and Ferragut 2015). The interactive effects between light and nutrient availability could influence the ability of the periphyton to assimilate and use $\mathrm{N}$ and $\mathrm{P}$, which could, in turn, reduce the development of the periphyton (Liess et al. 2009). However, the light:nutrient ratio can have a large impact in determining algal response (Fanta et al. 2010), or low light
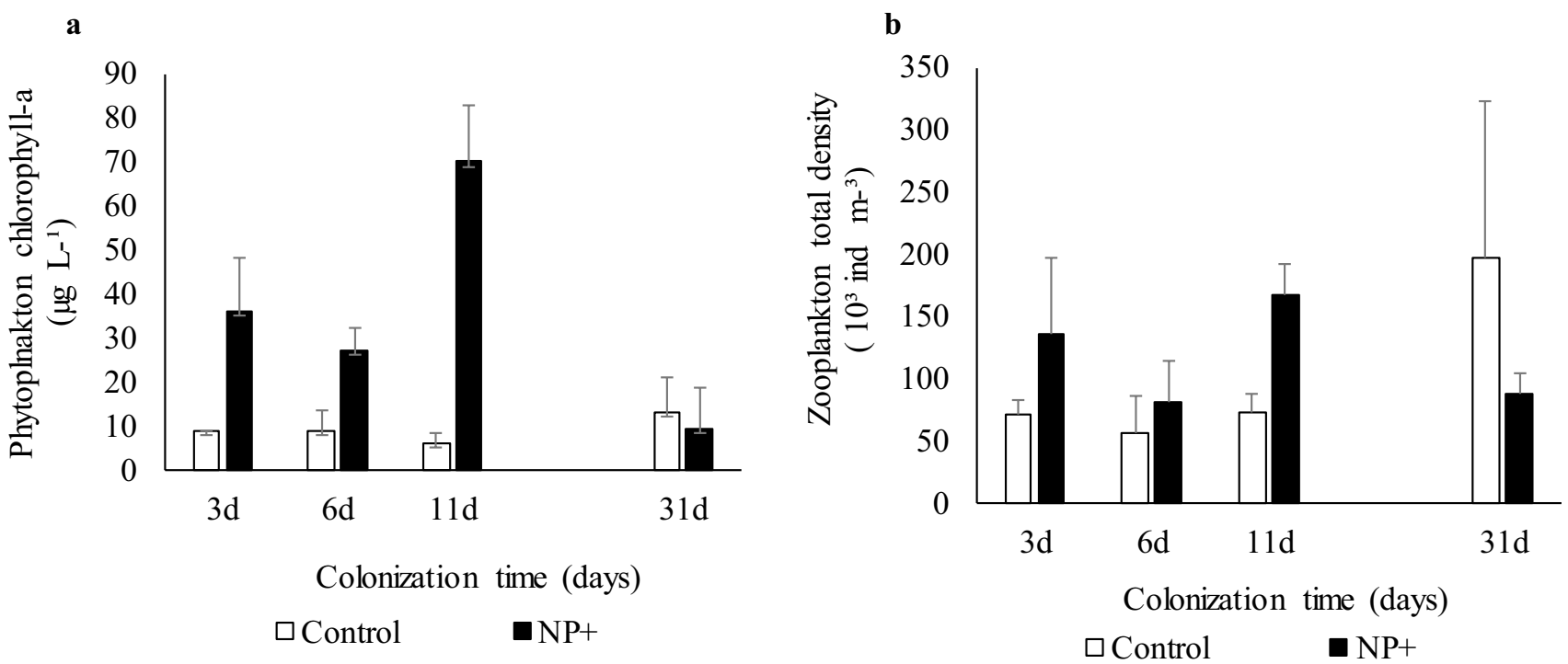

Fig. 6 Phytoplankton chlorophyll $a$ (a) and zooplankton total density (b) in control (C) and combined N and P addition treatment (NP+) during the enrichment continuous period (3rd, 6th, 11th days) and 20 days after its interruption (31st day) 
Table 2 Zooplankton taxa with relative density greater than $10 \%$ of total density $\left(\right.$ indm $^{-3}$ ) in the control and combined $\mathrm{N}$ and $\mathrm{P}$ addition treatment $(\mathrm{NP}+)$ on sampling day $(n=3)$

\begin{tabular}{|c|c|c|c|c|c|}
\hline Days & Treatment & Taxa & Group & Average density & $\%$ \\
\hline \multirow[t]{2}{*}{ 3rd day } & Control & Polyarthra spp. & Rotifers & 18,933 & 26.1 \\
\hline & $\mathrm{NP}+$ & Polyarthra spp. & Rotifers & 41,867 & 31.0 \\
\hline \multirow[t]{4}{*}{ 6th day } & Control & Nauplius & Copepods Calanoid & 7533 & 13.6 \\
\hline & & Polyarthra spp. & Rotifers & 7700 & 10.7 \\
\hline & $\mathrm{NP}+$ & Polyarthra spp. & Rotifers & 25,000 & 30.8 \\
\hline & & Chydorus pubescens & Cladocerans & 13,867 & 10.3 \\
\hline \multirow[t]{3}{*}{ 11th day } & Control & Polyarthra spp. & Rotifers & 9200 & 8.5 \\
\hline & & Nauplius & Copepods Cyclopoid & 5933 & 8.2 \\
\hline & $\mathrm{NP}+$ & Polyarthra spp. & Rotifers & 62,733 & 37.5 \\
\hline \multirow[t]{3}{*}{ 31st day } & Control & Asplanchna brightwellii & Rotifers & 49,800 & 25.4 \\
\hline & & Asplanchna sieboldi & Rotifers & 48,067 & 24.5 \\
\hline & NP & Gastropus stylifer & Rotifers & 19,867 & 22.9 \\
\hline
\end{tabular}

availability may not inhibit algae response to high nutrient concentration due to other factors (Rober et al. 2015). As the epiphyton response was different (Santos 2017, unpublished data), we believe that the position of the substrate in the water column may have promoted a light:nutrient ratio favorable to periphyton development, not masking the enrichment effect. The type and position of the substrate can be a determining factor in periphytic biomass accrual and algae community (Cattaneo and Amireault 1992; Vadeboncoeur et al. 2006).

Periphyton chlorophyll $a$ and algal density decreased after enrichment had ended, especially when compared to the 11th day of colonization. Differences in periphyton attributes between the control and NP+ treatment were minimized 20 days after enrichment had ended, thus showing the significant effect that enrichment has on periphyton structure. We observed that the periphyton responded promptly to the changes in nutrient availability in the water. Besides, the periphyton $\mathrm{P}$ content was significantly higher in the $\mathrm{NP}+$ treatment than the control (on days 3 and 14) during the enrichment period and significantly reduced after the enrichment stopped (on day 35). Thus, periphyton response to nutrient addition was also verified by the $\mathrm{P}$ content, which was coupled with water $\mathrm{P}$ concentration, as observed in other studies (e.g., Gaiser et al. 2004). The ability of periphyton to retain nutrients is an efficient competitive strategy, especially over time (Havens et al. 1999). On the other hand, periphyton dry mass showed exponential growth even after the enrichment period, indicating high participation of non-algal components in the community, including detrital components. The dissolved organic matter (DOM) can have a great influence on periphyton elemental composition (Frost et al. 2007). Therefore, our results showed that nutrient availability in the water was a determining factor for the development of the periphyton on artificial substrate.

We found that the nutrient enrichment and the effect of its interruption caused changes in the periphyton taxonomic structure throughout the experimental period. However, the combined $\mathrm{N}$ and $\mathrm{P}$ addition was not sufficient to alter the representativeness of algal classes in the periphyton, since Chrysophyceae was dominant during the enrichment period (first 11 days), especially Chromulina spp. After stopping enrichment, we found a negative effect on the Chromulina spp. density. On the 31 st day of colonization, the reduction in nutrient availability had a negative effect on periphyton biomass and algal density, favoring the substitution of Chrysophyceae (Chromulina spp.) with Bacillariophyceae (Gomphonema sp.). Chrysophyceae present competitive advantages, such as mixotrophy and the presence of flagella, which may explain their absolute dominance in the periphyton and their success during the enriched treatment (Sandgren 1988). Chromulina have characteristics that guarantee success in adverse conditions, including rapid reproduction, higher surface/volume ratio and presence of a flagellum, which facilitates the obtaining of resources (Happey-Wood 1988). Although the enrichment effect on the algal classes was only quantitative, the reduction of nutrient availability due to stopping enrichment changed the class-level structure, favoring diatoms, especially Gomphonema sp. Therefore, the interruption of additional nutrients changed the taxonomic structure of the periphytic algae community in the $\mathrm{NP}+$ treatment.

We have demonstrated that biomass and periphytic algae community structure responded promptly to $\mathrm{N}$ and $\mathrm{P}$ enrichment, as reported in numerous experiments (e.g., Havens et al. 1999; Hillebrand and Kahlert 2001). However, the interruption of the chemical disturbance reduced the accumulation of biomass and redirected taxonomic structure in the periphyton, including changes in class and species level. The effect of the enrichment on the periphyton on artificial substrate was not masked by an increase in the phytoplankton biomass and the zooplankton abundance in the presence of the high macrophyte coverage. Our findings have shown that periphyton on an artificial substrate is sensitive 
to $\mathrm{N}$ and $\mathrm{P}$ enrichment and the effects of its interruption in a mesotrophic reservoir, responding promptly to changes in nutrient availability in a highly competitive environment for resources, and with grazing pressure.

Acknowledgements The authors thank the PIBIC Institutional Program - CNPq (Conselho Nacional de Desenvolvimento Científico e Tecnológico) for a fellowship given to SAMS. The authors also thank Fundação de Amparo à Pesquisa do Estado de São Paulo (FAPESP) for doctoral grants for TRS (2013/03130-2) and financial support (2009/52253-4). The authors are very grateful to the students and technicians involved in laboratory work and in the field.

\section{References}

Andersen JM (1976) An ignition method for determination of total phosphorus in lake sediments. Water Res 10:329-331

APHA, AWWA, WEF (2005) Standard methods for the examination of water and wastewater, 21st edn. American Public Health Association, Washington, DC

Bicudo DC, Forti MC, Bicudo CEM (2002) Parque Estadual das Fontes do Ipiranga: unidade de conservação ameaçada pela urbanização de São Paulo. Editora Secretaria do Meio Ambiente do Estado de São Paulo, São Paulo

Casartelli MR, Ferragut C (2015) Influence of seasonality and rooted aquatic macrophyte on periphytic algal community on artificial substratum in a shallow tropical reservoir. Int Rev Hydrobiol 100:158-168

Cattaneo A, Amireault MC (1992) How artificial are artificial substrata for periphyton? J N Am Benthol Soc 11:244-256

Fanta SE, Hill WR, Smith TB, Roberts BJ (2010) Applying the light: nutrient hypothesis to stream periphyton. Freshw Biol 55:931-940

Ferragut C, Bicudo DC (2012) Effect of N and P enrichment on successional sequence of the periphytic algae community in a tropical oligotrophic reservoir. Limnology 13:131-141

Ferragut C, Rodello AF, Bicudo CEM (2010) Seasonal variability of periphyton nutrient status and biomass on artificial and natural substrates in a tropical mesotrophic reservoir. Acta Limnol Bras 22(4):397-409

Fonseca BM, Bicudo CEM (2011) Phytoplankton seasonal and vertical variations in a tropical shallow reservoir with abundant macrophytes (Ninfeias Pond, Brazil). Hydrobiologia 665:229-245

Frost PC, Cherrier CT, Larson JH, Bridgham S, Lamberti GA (2007) Effects of dissolved organic matter and ultraviolet radiation on the accrual, stoichiometry and algal taxonomy of stream periphyton. Freshwater Biol 52(2):319-330

Gaiser EE, Scinto LJ, Richards JH, Jayachandran K, Childers DL, Trexler JC, Jones RD (2004) Phosphorus in periphyton mats provides the best metric for detecting low-level P enrichment in an oligotrophic wetland. Water Res 38:507-516

Gaiser EE, Childers DL, Jones RD, Richards JH, Scinto LJ, Trexler JC (2006) Periphyton responses to eutrophication in the Florida Everglades: cross-system patterns of structural and compositional change. Limnol Oceanogr 51:617-630

Genkai-Kato M, Vadeboncoeur Y, Liboriussen L, Jeppesen E (2012) Benthic-planktonic coupling, regime shifts, and whole-lake primary production in shallow lakes. Ecology 93(3):619-631

Hammer O, Harper DAT, Ryan PD (2001) PAST: Paleontological statistics software packagefor education and data analysis. Palaeontol Electronica 4:1-9

Happey-Wood CM (1988) Ecology of freshwater planktonic green algae. In: Sandgren CD (ed) Growth and reproductive strategies of freshwater phytoplankton. Cambridge University Press, Cambridge, pp 175-226

Havens KE, East TL, Rodusky AJ, Sharfstein B (1999) Littoral periphyton responses to nitrogen and phosphorus: an experimental study in a subtropical lake. Aquat Bot 63:267-290

Havens KE, Hauxwell J, Tyler AC, Thomas S, Mc Glathery KJ, Cebrian J, Valiela I, Steinman AD, Hwang SJ (2001) Complex interactions between autotrophs in shallow marine and freshwater ecosystems: implications for community responses to nutrient stress. Environ Pollut 113:95-107

Hillebrand H, Kahlert M (2001) Effect of grazing and nutrient supply on periphyton biomass and nutrient stoichiometry in habitats of different productivity. Limnol Oceanogr 46:1881-1898

Hwang SJ, Havens KE, Steinman AD (1998) Phosphorus kinetics of planktonic and benthic assemblages in a shallow subtropical lake. Freshw Biol 40:729-745

Jones JI, Moss B, Eaton JW, Young JO (2000) Do submerged aquatic plants influence periphyton community composition for the benefit of invertebrate mutualists? Freshw Biol 43:591-604

Jones JI, Young JO, Eaton JW, Moss B (2002) The influence of nutrient loading, dissolved inorganic carbon and higher trophic levels on the interaction between submerged plants and periphyton. $\mathrm{J}$ Ecol 90:12-24

Liess A, Lange K, Schulz F, Piggott JJ, Matthaei CD, Townsend CR (2009) Light, nutrients and grazing interact to determine diatom species richness via changes to productivity, nutrient state and grazer activity. J Ecol 97:326-336

Lund JWG, Kipling C, Le-Cren ED (1958) The inverted microscope method of estimating algal number and the statistical basis of estimating by counting. Hydrobiologia 11:143-170

Mackereth FJH, Heron J, Talling JF (1978) Water analysis: some revised methods for limnologists. Titus Wilson and Son Ltda, Kendall

McCormick PV, Stevenson RJ (1998) Periphyton as a tool for ecological assessment and management in the Florida Everglades. J Phycol 34(5):726-733

Obertegger U, Flaim G (2015) Community assembly of rotifers based on morphological traits. Hydrobiologia 753:31-45

Olsen S, Chan F, Li W, Zhao S, Søndergaard M, Jeppesen E (2015) Strong impact of nitrogen loading on submerged macrophytes and algae: a long-term mesocosm experiment in a shallow Chinese lake. Freshw Biol 60:1525-1536

Peterson CG, Stevenson RJ (1992) Resistance and resilience of lotic algal communities: importance of disturbance timing and current. Ecology 73(4):1445-1461

Pompêo MLM, Moschini-Carlos V (2003) Macrófitas aquáticas e perifíton: aspectos ecológicos e metodológicos. Rima/Fapesp, São Carlos

Rasband W (2008) ImageJ. U.S. National Institutes of Health, Bethesda, Maryland. http://rsb.info.nih.gov/ij/. Accessed 20 Oct 2016

Rober AR, Stevenson RJ, Wyatt KH (2015) The role of light availability and herbivory on algal responses to nutrient enrichment in a riparian wetland, Alaska. J Phycol 51:528-535

Romo S, Miracle MR, Villena MJ, Rueda J, Ferriol C, Vicente E (2004) Mesocosm experiments on nutrient and fish effects on shallow lake food webs in a Mediterranean climate. Freshw Biol 49:1593-1607

Sandgren CD (1988) The ecology of chrysophyte flagellates: their growth and perennation strategies as freshwater phytoplankton. In: Sandgren CD (ed) Growth and reproductive strategies of freshwater phytoplankton. Cambridge University Press, Cambridge, pp 9-104

Sand-Jensen K, Borum J (1991) Interactions among phytoplankton periphyton and macrophytes in temperate freshwaters and estuaries. Aquat Bot 41:137-175 
Santos TR (2017) Dinâmica da comunidade de algas planctônicas, perifíticas e metafíticas em reservatório tropical raso: um estudo observacional e experimental. Doctoral thesis. Instituto de Botânica, SMA, São Paulo, Brazil

Sartory DP, Grobbelaar JU (1984) Extraction of chlorophyll $a$ from freshwater phytoplankton for spectrophotometric analysis. Hydrobiologia 114:177-187

Sekar R, Venugopalan VP, Nair KVK, Rao VNR (2002) Nutrients dynamics and successional changes in a lentic freshwater biofilm. Freshw Biol 47:1893-1907

Solorzano L (1969) Determination of ammonia in natural waters by the phenolhypochlorite method. Limnol Oceanogr 14(5):799-801

Souza ML, Pellegrini BG, Ferragut C (2015) Periphytic algal community structure in relation to seasonal variation and macrophyte richness in a shallow tropical reservoir. Hydrobiologia 755(1):183-196

Stevenson RJ (1996) An introduction to algal ecology in freshwater benthic habitats. In: Stevenson RJ, Bothwell ML, Lowe RL (eds) Algal ecology: freshwater benthic ecosystems. Academic Press, San Diego, pp 3-30

Stevenson RJ (1997) Scale-dependent determinants and consequences of benthic algal heterogeneity. J N Am Benthol Soc 16:248-262
Stevenson RJ, Smol JP (2003) Use of algae in environmental assessments. In: Wehr JD, Sheath RG (eds) Freshwater algae of North America ecology and classification. Elsevier Science (USA), San Diego, pp 775-804

Strickland JDH, Parsons TR (1960) A manual of seawater analysis. Bull Fish Res Board Can 125:1-185

Utermöhl H (1958) Zur Vervollkommnung der quantitativen Phytoplankton-Methodik. Mitt Intern Verein Limnol 9:1-38

Vadeboncoeur Y, Steinman AD (2002) Periphyton function in lake ecosystems. Sci World J 2:1-20

Vadeboncoeur Y, Kalff J, Christoffersen K, Jeppesen E (2006) Substratum as a driver of variation in periphyton chlorophyll and productivity in lakes. J N Am Benthol Soc 25:379-392

Virro T (1995) The genus Polyarthra in Lake Peipsi. Hydrobiologia 313(314):351-357

Zhang Z, Cao Y, Jeppesen E, Wei L (2016) The response of Vallisneria spinulosa (Hydrocharitaceae) and plankton to pulse addition of inorganic nitrogen with different loading patterns. Hydrobiologia 767:175-184 